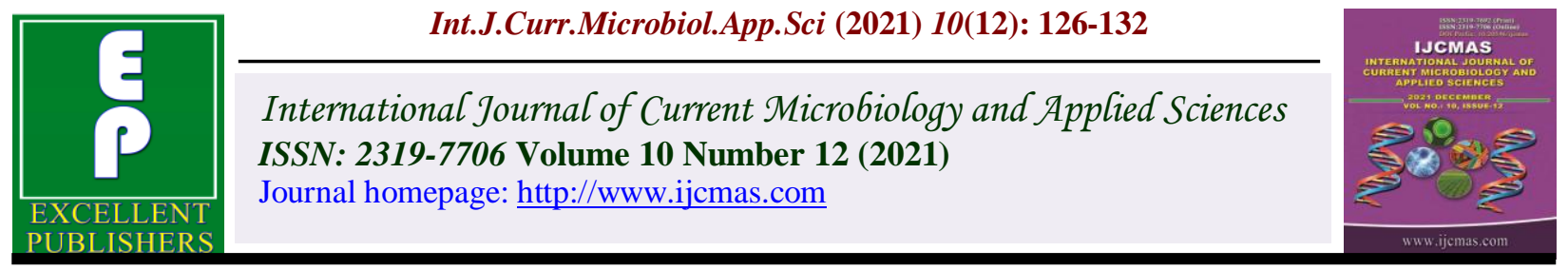

\title{
Validation of CERES-RICE Model in Wetland Condition using DSSAT-4.5
}

\author{
A. P. Deshmukh*, S. B. Kharbade, N. V. Kashid, S. V. Jadhav and R. Balasubramanian \\ Department of Agricultural Meteorology, Centre For Advanced Faculty Training (CAFT) in \\ Agricultural Meteorology, College of Agriculture, Pune - 411005 Maharashtra, India \\ *Corresponding author
}

\section{A B S T R A C T}

Keywords

DSSAT, Rice,

Percent error,

Validation

Article Info

Received:

05 November 2021

Accepted:

30 November 2021

Available Online:

10 December 2021
An agro-meteorological investigation was undertaken on "Crop weather pest relationship and validation of DSSAT model for rice varieties under different transplanting dates", during kharif, 2016 and 2017 at Agricultural Research Station Farm, Vadgaon Maval, Dist. Pune, under Mahatma Phule Krishi Vidyapeeth, Rahuri, for the purpose to evaluate the heat efficiency of rice crop. An experiment was laid out in split plot design with three replications. The treatment comprised of four sowing dates viz., $\mathrm{S}_{1}: 26^{\text {th }}$ MW (25 June-1 July), $\mathrm{S}_{2}: 28^{\text {th }}$ MW (9 July-15 July), $\mathrm{S}_{3}: 30$ MW (23 July29 July) and $S_{4}: 32^{\text {nd }}$ MW (06 August -12 August) as main plot treatments and four varieties viz., $\mathrm{V}_{1}$ : VDN-99-29 (Phule Samruddhi), $\mathrm{V}_{2}$ : VDN-3-5118 (Indrayani), $\mathrm{V}_{3}$ : IET-13549 (Bhogavati) and $\mathrm{V}_{4}:$ RDN-99-1 (Phule Radha) as sub plot treatments.

\section{Introduction}

Rice (Oryza sativa L.) is a staple food for more than 65 per cent of the people and it provides employment and livelihood security to 70 per cent of Indian population.

India grows rice in highly diverse conditions starting from below sea levels to hill as high as $>2000$ meters. India ranks first in area with about $44 \mathrm{~m}$. ha under rice and second in production with 104.8 million tones with an average productivity of $2390 \mathrm{~kg} \mathrm{ha}^{-1}$ (Rami et al., 2016). Rice provides 21 per cent of global human per capita energy and 15 per cent of per capita protein. Although rice protein ranks high in nutritional quality among cereals, protein content is modest.

Crop model is a mathematical equation or the set of equations, which represents the behaviour of a system (Thornley, 1976). Crop models that use specific weather, soil, genetic and management information offer a good opportunity for assisting farm manager in several aspects of decision making to attain 
their goals. The crop growth models are helpful to assess the impact of climate change on the stability of crop production under different management options (Hoogenboom et al., 1995).

The models of the CERES (Crop Estimation through Resource and Environment Synthesis) are employed to estimate the productivity of grains such as maize, rice, wheat, barley, millet and sorghum.

The CSM-CERES-Rice is part of the modular system called Crop System Model (CSM) present in the Decision Support System for Agro technology Transfer (DSSAT) version 4.5 (Jones et al., 2003). It is based on the model CERES-Rice that describes the production and partitioning of the plant biomass and its phenology. The model interconnects the processes of environmental variations and plant management (Carbone et al., 2003).

Validation may be defined as comparison of predicted values with observed values from the experiment. Validation increases our confidence in the model since the climatic management and fertilizer practices make much more effect on production of rice. After validation of the model it can be used to predict the grain yield of sorghum.

\section{Materials and Methods}

The present experiments related investigation entitled, "Crop weather pest relationship and validation of DSSAT model for Rice varieties under different transplanting dates" were conducted at Agriculture Research Station Farm, Vadgaon Maval, Tal. Dist. (M.S.) during kharif seasons of 2016-17 and 2017-18, to identify optimum transplanting date for Rice, to develop crop weather relationships, to develop pest weather relations and to validate the DSSAT model.

\section{Experimental Details}

The experiment was conducted in a split -plot design with three replications and sixteen treatment combinations were formed considering different varieties and transplanting. The details are listed below.

Name of crop : Rice

Varieties

VDN-99-29 (Phule Samrudhi)

VDN-3-51-18 (Indrayani)

IET-13549 (Bhogavati)

RDN-99-1 (Phule Radha)

Number of treatment combinations : 16

Number of replications : 3

Number of plots : 48

Experimental Design : Split plot Design

\section{Plot size}

Gross Plot: $4.80 \mathrm{~m}$ x $3.60 \mathrm{~m}$

Net Plot: : $4.0 \mathrm{~m}$ x $3.0 \mathrm{~m}$

Spacing : $20 \mathrm{~cm} \mathrm{x} 15 \mathrm{~cm}$

Seed rate : $20 \mathrm{~kg} \mathrm{ha}^{-1}$

Fertilizer dose : 175: 60: 60 NPK kg ha ${ }^{-1}$

\section{Seasons}

Kharif, 2016

Kharif, 2017 
Place of research work : Agricultural Research Station Farm, Vadgaon Maval, Tal. Maval, Dist. Pune

\section{Transplanting dates}

$\mathrm{S}_{1}: 26^{\text {th }} \mathrm{MW}$ (25 June-1 July)

$\mathrm{S}_{2}: 28^{\text {th }} \mathrm{MW}$ (16 July-15July)

$\mathrm{S}_{3}: 30 \mathrm{MW}$ (23 July-29July)

Validation is the comparison of the results of model simulations with observations that were not used for the calibration.

The experimental data collected will be used for independent model validation. Statistical index generally used for model validation is,

RMSE (Root Mean Square Error) $=\sqrt{\frac{\sum_{\mathrm{t}=1}^{\mathrm{n}}(\mathrm{Pi}-\mathrm{Oi})^{2}}{\mathrm{n}}}$

Where Pi and Oi refer to the predicted and observed values for the studied variables (e.g. grain yield and total biomass), respectively and $\mathrm{n}$ is the mean of the observed variables.

The normalized root mean square error (NRMSE) that is expressed in per cent, calculated as explained by Loague and Green (1991) with the help of following Equation;

NRMSE $=\sqrt{\frac{\sum_{t=1}^{n}\left(\mathrm{Pi}_{i}-\mathrm{O}_{i}\right)^{2}}{\mathrm{n}}} \times \frac{100}{\mathrm{M}}$

Where, $\mathrm{n}$ is the number of observations, $\mathrm{Pi}$ and Oi are predicted and observed values respectively and $\mathrm{M}$ is the observed mean value.

The simulation is considered excellent with RMSE $<10$ per cent, good if 10-20 per cent, fair if 20-30 per cent, and poor $>30$ per cent for yield and other growth parameters.

\section{Results and Discussion}

\section{Phenology}

\section{Days to50 per cent flowering}

The mean simulated number of days to 50 per cent flowering for the varieties was over estimated by the model but it was found to be nearer to the observed values Table 1 .

The Coefficient of determination $\left(\mathrm{R}^{2}\right)$ and NRMSE (Normal Root Mean Square Error) values for simulations were found to be good enough for the model.

The RMSE (Root Mean Square Error) values for simulations were $1.55,2.10,2.6$ and 1.00 for VDN-99-29 ( $\left.\mathrm{V}_{1}\right)$, VDN-3-51-18 $\left(\mathrm{V}_{2}\right)$, IET13549 $\left(\mathrm{V}_{3}\right)$ and RDN-99-1 $\left(\mathrm{V}_{4}\right)$ respectively According to Loague and Green (1991), if NRMSE is between 1-10\%, simulations are good.

\section{Physiological maturity}

The simulated days to physiological maturity was found to be under estimated by the model for all varieties but the difference was not more than of 20 days. The RMSE (Root Mean Square Error) values for simulations were $1.22,1.13,1.22$ and 1.44 for VDN-99-29 $\left(\mathrm{V}_{1}\right)$, VDN-3-51-18 $\left(\mathrm{V}_{2}\right)$, IET13549 $\left(\mathrm{V}_{3}\right)$ and RDN99-1 $\left(\mathrm{V}_{4}\right)$ respectively.

The coefficient of determination $\left(\mathrm{R}^{2}\right)$ and NRMSE values that was obtained are given in Table 2. From the values it was clear that the simulations were good by the model.

\section{Leaf area}

Data pertaining to leaf area simulations are presented in (Table 3). The mean simulated leaf area was 20.7 as against observed leaf area of 20.94 in case of VDN-99-29( $\left.\mathrm{V}_{1}\right)$. 
Int.J.Curr.Microbiol.App.Sci (2021) 10(12): 126-132

Table.1 Number for days to $50 \%$ flowering

\begin{tabular}{|c|c|c|c|c|c|c|c|c|}
\hline Sowing & \multicolumn{8}{|c|}{ Number of days to $50 \%$ flowering } \\
\hline \multirow[t]{2}{*}{ Variety } & \multicolumn{2}{|c|}{$\mathbf{V}_{1}$} & \multicolumn{2}{|c|}{$\mathbf{V}_{2}$} & \multicolumn{2}{|c|}{$\mathbf{V}_{3}$} & \multicolumn{2}{|c|}{$\mathbf{V}_{4}$} \\
\hline & $\begin{array}{c}\text { Simula } \\
\text { ted }\end{array}$ & $\begin{array}{c}\text { Observ } \\
\text { ed }\end{array}$ & $\begin{array}{c}\text { Simula } \\
\text { ted }\end{array}$ & $\begin{array}{c}\text { Observ } \\
\text { ed }\end{array}$ & $\begin{array}{c}\text { Simula } \\
\text { ted }\end{array}$ & $\begin{array}{c}\text { Observ } \\
\text { ed }\end{array}$ & $\begin{array}{c}\text { Simula } \\
\text { ted }\end{array}$ & $\begin{array}{c}\text { Observ } \\
\text { ed }\end{array}$ \\
\hline$S_{1}(2016)$ & 93 & 95 & 98 & 100 & 100 & 101 & 76 & 77 \\
\hline$S_{2}(2016)$ & 98 & 100 & 97 & 103 & 97 & 103 & 80 & 81 \\
\hline $\mathrm{S}_{3}(2016)$ & 90 & 93 & 93 & 95 & 96 & 99 & 75 & 76 \\
\hline $\mathrm{S}_{4}(2016)$ & 90 & 92 & 90 & 92 & 94 & 94 & 72 & 71 \\
\hline $\mathrm{S}_{1}(2017)$ & 96 & 98 & 101 & 102 & 101 & 103 & 80 & 82 \\
\hline $\mathrm{S}_{2}(2017)$ & 97 & 99 & 101 & 103 & 105 & 104 & 85 & 87 \\
\hline $\mathrm{S}_{3}(2017)$ & 98 & 100 & 101 & 103 & 104 & 103 & 79 & 81 \\
\hline $\mathrm{S}_{4}(2017)$ & 96 & 98 & 100 & 101 & 104 & 103 & 79 & 78 \\
\hline Mean & 94.75 & 96.87 & 97.62 & 99.87 & 100.125 & 101.25 & 78.25 & 79.12 \\
\hline MAE & \multicolumn{2}{|c|}{0.18} & \multicolumn{2}{|c|}{0.21} & \multicolumn{2}{|c|}{0.15} & \multicolumn{2}{|c|}{0.12} \\
\hline MBE & \multicolumn{2}{|c|}{-0.18} & \multicolumn{2}{|c|}{-0.21} & \multicolumn{2}{|c|}{-0.15} & \multicolumn{2}{|c|}{-0.12} \\
\hline RMSE & \multicolumn{2}{|c|}{1.55} & \multicolumn{2}{|c|}{2.10} & \multicolumn{2}{|c|}{2.06} & \multicolumn{2}{|c|}{1.0} \\
\hline PE & \multicolumn{2}{|c|}{1.60} & \multicolumn{2}{|c|}{2.10} & \multicolumn{2}{|c|}{2.04} & \multicolumn{2}{|c|}{1.0} \\
\hline
\end{tabular}

Table.2 Number of days to physical maturity

\begin{tabular}{|c|c|c|c|c|c|c|c|c|}
\hline \multirow{3}{*}{$\begin{array}{l}\text { Sowing } \\
\text { window } \\
\text { Variety }\end{array}$} & \multicolumn{8}{|c|}{ Number of days to physical maturity } \\
\hline & \multicolumn{2}{|c|}{$\mathbf{V}_{1}$} & \multicolumn{2}{|c|}{$\mathbf{V}_{2}$} & \multicolumn{2}{|c|}{$\mathbf{V}_{3}$} & \multicolumn{2}{|c|}{$\mathbf{V}_{4}$} \\
\hline & $\begin{array}{c}\text { Simul } \\
\text { ated }\end{array}$ & $\begin{array}{c}\text { Obser } \\
\text { ved }\end{array}$ & $\begin{array}{c}\text { Simul } \\
\text { ated }\end{array}$ & $\begin{array}{c}\text { Obser } \\
\text { ved }\end{array}$ & $\begin{array}{l}\text { Simul } \\
\text { ated }\end{array}$ & $\begin{array}{c}\text { Obser } \\
\text { ved }\end{array}$ & $\begin{array}{c}\text { Simul } \\
\text { ated }\end{array}$ & $\begin{array}{c}\text { Obser } \\
\text { ved }\end{array}$ \\
\hline$S_{1}(2016)$ & 122 & 124 & 150 & 149 & 152 & 151 & 116 & 115 \\
\hline $\mathrm{S}_{2}(2016)$ & 130 & 129 & 156 & 155 & 152 & 154 & 123 & 121 \\
\hline $\mathrm{S}_{3}(2016)$ & 125 & 127 & 140 & 142 & 147 & 148 & 113 & 114 \\
\hline $\mathrm{S}_{4}(2016)$ & 124 & 125 & 137 & 138 & 138 & 140 & 110 & 113 \\
\hline $\mathrm{S}_{1}(2017)$ & 125 & 127 & 153 & 152 & 156 & 154 & 118 & 117 \\
\hline $\mathrm{S}_{2}(2017)$ & 134 & 132 & 159 & 158 & 155 & 157 & 120 & 123 \\
\hline $\mathrm{S}_{3}(2017)$ & 132 & 130 & 143 & 145 & 149 & 151 & 115 & 116 \\
\hline $\mathrm{S}_{4}(2017)$ & 125 & 128 & 138 & 140 & 138 & 143 & 113 & 115 \\
\hline Mean & 127.12 & 126 & 147 & 148 & 148.37 & 149.75 & 116 & 117 \\
\hline MAE & \multicolumn{2}{|c|}{0.06} & \multicolumn{2}{|c|}{0.01} & \multicolumn{2}{|c|}{0.06} & \multicolumn{2}{|c|}{0.04} \\
\hline MBE & \multicolumn{2}{|c|}{-0.06} & \multicolumn{2}{|c|}{-0.01} & \multicolumn{2}{|c|}{-0.06} & \multicolumn{2}{|c|}{-0.01} \\
\hline RMSE & \multicolumn{2}{|c|}{1.22} & \multicolumn{2}{|c|}{1.13} & \multicolumn{2}{|c|}{1.22} & \multicolumn{2}{|c|}{1.44} \\
\hline PE & \multicolumn{2}{|c|}{0.96} & \multicolumn{2}{|c|}{0.59} & \multicolumn{2}{|c|}{0.82} & \multicolumn{2}{|c|}{1.24} \\
\hline
\end{tabular}


Table.3 Leaf area

\begin{tabular}{|c|c|c|c|c|c|c|c|c|}
\hline \multirow{2}{*}{$\begin{array}{c}\text { Sowing } \\
\text { times }\end{array}$} & \multicolumn{2}{|c|}{$\mathbf{V}_{\mathbf{1}}$} & \multicolumn{2}{c|}{$\mathbf{V}_{\mathbf{2}}$} & \multicolumn{2}{c|}{$\mathbf{V}_{\mathbf{3}}$} & \multicolumn{2}{c|}{$\mathbf{V}_{\mathbf{4}}$} \\
\cline { 2 - 11 } & $\begin{array}{c}\text { Simul } \\
\text { ated }\end{array}$ & $\begin{array}{c}\text { Obser } \\
\text { ved }\end{array}$ & $\begin{array}{c}\text { Simul } \\
\text { ated }\end{array}$ & $\begin{array}{c}\text { Obser } \\
\text { ved }\end{array}$ & $\begin{array}{c}\text { Simul } \\
\text { ated }\end{array}$ & $\begin{array}{c}\text { Obser } \\
\text { ved }\end{array}$ & $\begin{array}{c}\text { Simul } \\
\text { ated }\end{array}$ & $\begin{array}{c}\text { Obser } \\
\text { ved }\end{array}$ \\
\hline $\mathrm{S}_{1}(2016)$ & 21.7 & 22.5 & 21.6 & 22.3 & 16.7 & 17.5 & 14.7 & 15.3 \\
\hline $\mathrm{S}_{2}(2016)$ & 24.9 & 23.6 & 21.5 & 22.5 & 17.5 & 18.3 & 14.0 & 15.2 \\
\hline $\mathrm{S}_{3}(2016)$ & 20.6 & 20.1 & 18.3 & 18.7 & 13.9 & 13.2 & 12.6 & 13.6 \\
\hline $\mathrm{S}_{4}(2016)$ & 12.6 & 13.6 & 12.0 & 13.2 & 11.8 & 12.45 & 11.7 & 12.8 \\
\hline $\mathrm{S}_{1}(2017)$ & 23.7 & 22.9 & 21.8 & 20.9 & 18.2 & 18.9 & 15.7 & 16.5 \\
\hline $\mathrm{S}_{2}(2017)$ & 26.6 & 27.89 & 23.5 & 24.6 & 19.1 & 18.7 & 15.0 & 16.7 \\
\hline $\mathrm{S}_{3}(2017)$ & 22.0 & 23.1 & 19.8 & 20.4 & 15.01 & 15.09 & 13.5 & 14.2 \\
\hline $\mathrm{S}_{4}(2017)$ & 13.5 & 13.9 & 13.1 & 14.67 & 12.09 & 14.67 & 12.9 & 13.5 \\
\hline Mean & 20.7 & 20.94 & 18.95 & 19.65 & 15.53 & 16.10 & 13.76 & 14.72 \\
\hline MAE & 0.16 & 0.28 & 0.14 & 0.23 \\
\hline MBE & -0.16 & -0.28 & -0.15 & -0.15 \\
\hline RMSE & 1.78 & 2.89 & 2.67 & 1.89 \\
\hline PE & 1.82 & \multicolumn{2}{|c|}{2.23} & 2.56 & \multicolumn{2}{|c|}{1.67} \\
\hline
\end{tabular}

Table.4 Grain yield

\begin{tabular}{|c|c|c|c|c|c|c|c|c|}
\hline $\begin{array}{c}\text { Sowing } \\
\text { window }\end{array}$ & \multicolumn{7}{|c|}{ Grain yield } \\
\hline Variety & \multicolumn{2}{|c|}{$\mathbf{V}_{\mathbf{1}}$} & \multicolumn{2}{c|}{$\mathbf{V}_{\mathbf{2}}$} & \multicolumn{2}{c|}{$\mathbf{V}_{\mathbf{3}}$} & \multicolumn{2}{c|}{$\mathbf{V}_{\mathbf{4}}$} \\
\cline { 2 - 12 } & $\begin{array}{c}\text { Simul } \\
\text { ated }\end{array}$ & $\begin{array}{c}\text { Obser } \\
\text { ved }\end{array}$ & $\begin{array}{c}\text { Simul } \\
\text { ated }\end{array}$ & $\begin{array}{c}\text { Obser } \\
\text { ved }\end{array}$ & $\begin{array}{c}\text { Simul } \\
\text { ated }\end{array}$ & $\begin{array}{c}\text { Obser } \\
\text { ved }\end{array}$ & $\begin{array}{c}\text { Simul } \\
\text { ated }\end{array}$ & $\begin{array}{c}\text { Obser } \\
\text { ved }\end{array}$ \\
\hline $\mathrm{S}_{1}(2016)$ & 60.4 & 59.6 & 52.1 & 53.8 & 46.0 & 45.9 & 42.1 & 40.3 \\
\hline $\mathrm{S}_{2}(2016)$ & 69.2 & 68.3 & 60.2 & 59.1 & 46 & 48.0 & 38.1 & 38.5 \\
\hline $\mathrm{S}_{3}(2016)$ & 57 & 56.4 & 52.4 & 50.3 & 40.2 & 38.1 & 36.3 & 34.5 \\
\hline $\mathrm{S}_{4}(2016)$ & 36.4 & 34.7 & 34.2 & 32.9 & 33.1 & 32.4 & 35.2 & 32.2 \\
\hline $\mathrm{S}_{1}(2017)$ & 64.2 & 65.0 & 61.3 & 59.9 & 52.2 & 50.1 & 45 & 43.2 \\
\hline $\mathrm{S}_{2}(2017)$ & 74.2 & 73.0 & 66.1 & 64.5 & 54.2 & 52.4 & 43.1 & 41.2 \\
\hline $\mathrm{S}_{3}(2017)$ & 61.2 & 60.4 & 55.3 & 54.3 & 42.1 & 41.2 & 38.1 & 37.0 \\
\hline $\mathrm{S}_{4}(2017)$ & 36.1 & 37.1 & 34.2 & 35.9 & 34.3 & 35.4 & 35.2 & 35.5 \\
\hline Mean & 57.33 & 56.81 & 51.97 & 51.33 & 43.51 & 42.93 & 39.13 & 37.8 \\
\hline MAE & 0.09 & 0.08 & 0.07 & 0.14 \\
\hline MBE & 0.09 & 0.08 & 0.07 & 0.14 \\
\hline RMSE & 1.15 & 1.11 & 1.17 & 1.37 \\
\hline PE & 2.61 & 2.16 & 2.74 & 3.62 \\
\hline
\end{tabular}


The mean simulated leaf area and observed leaf area were 18.95 and $19.65,15.53$ and $16.10,13.76$ and in 14.72 in case of VDN-351-18 $\left(\mathrm{V}_{2}\right)$, IET13549 $\left(\mathrm{V}_{3}\right)$ and RDN-99-1 $\left(\mathrm{V}_{4}\right)$, respectively.

The RMSE (Root Mean Square Error) values for simulations were 1.82, 2.23, 2.56 and 1.67 for VDN-99-29 $\left(\mathrm{V}_{1}\right)$, VDN-3-51-18 $\left(\mathrm{V}_{2}\right)$, IET$13549\left(\mathrm{~V}_{3}\right)$ and RDN-99-1 $\left(\mathrm{V}_{4}\right)$ respectively. Simulated phenophases with good RMSE values are presented in Table 3.

\section{Grain yield ( $\left.\mathrm{kg} \mathrm{ha}^{-1}\right)$}

The mean simulated and observed grain yield was found to be closer for all the varieties (Table 4).

The coefficient of determination $\left(\mathrm{R}^{2}\right)$ for the varieties was found good as reported by Tripathi et al., 2016 and NRMSE (Normal Root Mean Square Error) values for simulations were found to be good enough for the model.

The RMSE (Root Mean Square Error) values for simulations were $1.15,1.11,1.17$ and 1.37 for VDN-99-29 (V1), VDN-3-51-18 ( $\left.\mathrm{V}_{2}\right)$, IET13549 $\left(\mathrm{V}_{3}\right)$ and RDN-99-1 $\left(\mathrm{V}_{4}\right)$, respectively.

Simulated phenophases with good RMSE values are presented in (Table 4).If NRMSE is between 1-10\%, simulations are good (Loague and Green, 1991).

DSSAT model was found able to predict the phenophases and grain yield of all the varieties with good $\mathrm{R}^{2}$ and NRMSE values. It could be used for future climate change studies under wet condition. The climate change has become a great issue concerning the agricultural productions. Hence there is a need to select suitable crops and suitable dates of sowing for the changing weather conditions. Crop simulation models will find out the crop-environment relationships and thus helps in selecting suitable cultivars for a particular region. Validation of such crop simulation models should be carried out in different locations to find its suitability in predictions.

\section{References}

Carbone, G. J., Kiechle, W., Locke, C., Mearns, L. O., Mc Daniel, L., and Downton, M. 2003. Response of soybean and sorghum to varying spatial scales of climate change scenarios in the South-eastern United States. Climatic Change.60:73-98.

Hoogenboom, G., Tsuji, G. Y., Jones, J. W., Singh, U., Godwin, D. C., Pickering, N. B. and Curry, R. B. 1995. Decision support system to study climate change impacts on crop production. p. 51-75. In C. Rosenzweig et al., (ed.) Climate change and agriculture : Analysis of potential international impacts. ASA Spec. Publ. No. 59.Am. Soc of Agron., Madison, WI. Hundal.

Jones, J. W., Hoogenboom, G., Porter, C. H., Boote, K. J., Batchelor, W. D. and Hunt, L. A. 2003. The DSSAT cropping system model. Eur. J. Agron. 18(5):235-265.

Loague, K. and Green, R. E. 1991. Statistical and graphical methods for evaluating solute transport models: overview and application. J. Contam. Hydrol. 7(1): 51-73.

Thornley, J. H. M. 1976. Modeling as a tool in plant physiology. Environmental effects on crop physiology. (Eds. Landsberg, J. J. and Cutting, C. V.) Academic press New York USA: 339359. 


\section{How to cite this article:}

Deshmukh, A. P., S. B. Kharbade, N. V. Kashid, S. V. Jadhav and Balasubramanian, R. 2021.

Validation of CERES-RICE Model in Wetland Condition using DSSAT-4.5.

Int.J.Curr.Microbiol.App.Sci. 10(12): 126-132. doi: https://doi.org/10.20546/ijcmas.2021.1012.013 